AKSYANA: JURNAL AKUNTANSI DAN KEUANGAN ISLAM

Vol. 01, No. 01 September 2021, hlm.49-56

Available at https://jurnal.unsur.ac.id/JA/index

\title{
SIGNIFIKANSI PERDAGANGAN DAN UANG SEBAGAI MEDIA TRANSAKSI DALAM KONTEKS KEBIJAKAN MONETER PADA MASA SEBELUM DAN AWAL PEMERINTAHAN ISLAM
}

Irpan Jamil

Fakultas Ekonomi dan Bisnis Islam,Universitas Suryakancana

irpanjamil76@gmail.com

\begin{tabular}{l|l|l|} 
Masuk: Juli 2021 & Penerimaan: Agustus 2021 & Publikasi: September 202 \\
\hline
\end{tabular}

\begin{abstract}
ABSTRAK
Permasalahan ekonomi yang di hadapi umat manusia sama tuanya dengan usia keberadaan manusia di muka bumi ini. Masalah utama dalam penelitian ini adalah kebijakan moneter seperti apa yang diterapkan pada masa sebelum dan awal pemerintahan Islam kaitannya dengan perdagangan dan uang sebagai aktivitas dan media transaksi pada saat itu.Tujuan penelitian ini adalah untuk menganalisis signifikansi perdagangan dan uang sebagai media transaksi yang dipakai serta kondisi yang melatarbelakanginya dan dinamika yang tejadi pada saat itu. Metode yang digunakan dalam penelitian ini yaitu metode analisis deskriftif dengan pendekatan aspek historis. Hasil dan temuan dalam penelitian ini menunjukkan bahwa hubungan internasional perdagangan mempunyai peran yang strategis terutama dengan dijadikannya Mekkah sebagai pusat perdaganga internasional. Temuan dalam penelitian ini juga menunjukkan bahwa produk, mata uang yang digunakan cukup memberikan kejelasan bahwa Mekkah sudah menjadi tempat "perbankan"
\end{abstract}

Kata kunci : Ilaf, al-Haram, principal outlet, suftaja.

\begin{abstract}
ABSTRCT
The economic problems faced by mankind are as old as the age of human existence on this earth. The main problem in this study is what kind of monetary policy was applied in the period before and the beginning of Islamic rule in relation to trade and money as an activity and transaction medium at that time. behind it and the dynamics that occurred at that time. The method used in this research is descriptive analysis method with historical aspect approach. The results and findings in this study indicate that international trade relations have a strategic role, especially by making Mecca a center for international trade. The findings in this study also show that the product, the currency used is sufficient to provide clarity that Mecca has become a place of "banking".
\end{abstract}

Keywords : Ilaf, al-Haram, principal outlet, suftaja

\section{A. PENDAHULUAN}

Kontribusi kaum muslimin yang sangat besar terhadap kelangsungan dan perkembangan pemikiran ekonomi pada khususnya dan peradaban dunia pada umumnya telah di abaikan oleh para Ilmuwan Barat. Menurut Chapra, meski sebagian kesalahan terletak di tangan umat Islam karena tidak mengartikulasikan secara memadai kontribusi kaum muslimin, namun Barat memiliki andil dalam hal 
ini, karena tidak ada penghargaan yang layak atas kontribusi peradaban lain bagi kemajuan pengetahuan manusia (M. Umer Chapra, The Future of Economics : An Islamic Perspective (Jakarta : Shariah Economics and Banking Institute,2001) hlm. 150)

Adalah hal yang sangat sulit untuk di pahami mengapa para ilmuwan Barat tidak menyadari bahwa sejarah pengetahuan merupakan suatu proses yang berkesinambungan, yang dibangun diatas fondasi yang diletakan para ilmuan generasi sebelumnya. Jika proses evolusi ini disadari dengan sepenuhnya, menurut Chapra, Schumpeter mungkin tidak mengasumsikan adanya kesenjangan yang besar selama 500 tahun, tetapi mencoba menemukan fondasi di atas mana para ilmuwan Skolastik dan Barat mendirikan bangunan intelektual mereka.

Berbagai peraktik dan kebijakan ekonomi yang berlangsung pada masa Rasullulah SAW, dan al-khulafa al-rasyidin merupakan contoh empiris yang dijadikan pijakan bagi para cendikiawan muslim dalam melakukan konsep dan ragam teori ekonominya. Satu hal yang jelas, fokus per hatian mereka tertuju pada pemenuhan kebutuhan, keadilan, efisiensi pertumbuhan dan kebebasan,yang tidak lain merupakan objek utama yang menginspirasikan pemikiran ekonomi Islam sejak masa awal

Tulisan ini ingin mengangkat mengenai kajian literatur sejarah pemikiran Ekonomi Islam yang membahas mengenai signifikasi perdagangan dan uang sebagai media transaksi dalam kontek kebijakan moneter pada masa awal pemerintahan Islam.

\section{B. PEMBAHASAN}

\section{Konsep perdagangan di jazirah Arab sebelum Islam}

a. Perdagangan Lokal dan Internasional

Mekkah, secara geografis merupakan lokasi yang menguntungkan dan strategis yang membentang pada salah satu lintasan terbesar perdagangan dunia. Mekkah berada pada wilayah antara Asia dan Afrika dan menyebrangi rute-rute kekaisaran Iraq dan Persia melalui Hira dan al-Uballa, atau dari Timur Jauh hingga ke Cina, Ethiopia (Abbisinia), 
Somalia, Afrika, Syria dan lintasan Yordan, di selatan ke Yaman atau Arabia Selatan, Samudra India di selatan atau barat daya yang mengarah menghubungkan laut merah dan barat laut yang berdampingan dengan Mesir dan selatan Eropa menyebrang ke laut tengah (Abdullah Alwi Haji Hassan, Sales and Contracs in Early Islamic Commercial Law, Islamabad: IRI-(International Islamic University, 1994, hlm.3).

Sebagai lintasan perdagangan dan kondisi geografis yang tidak produktif untuk usaha lain, Mekkah benar-benar menjadi pusat perdagangan lokal dan internasional. Perdagangan lokal sejak lama sudah dilakukan sesuai kondisi wilayah yang tidak mendukung untuk kegiatan usaha lain selain perdagangan, sebagaimana disebutkan diatas. Adapun perdagangan internasional seperti ke Yaman, Syria, Irak dan Palestina sudah dilakukan sejak lama. Para sejarawan berbeda pendapat mengenai permulaan terjadinya perdagangan internasional di Mekkah. Ada yang mengatakan, perdagangan inetrnasional dimulai sejak Hashim (kakek Nabi Muhammad) pergi ke Syria. Dia adalah pedagang pertama yang melakukan praktik perjalanan perdagangan bagi orang-orang Mekkah. Perjalanan dagang pada musim dingin ke Yaman dan musim panas ke Syam atau Syria.

Perjalanan Hashim ini, ternyata tidak semata- mata melakukan dagang terhadap barang dagangannya, tetapi juga melakukan hubungan kerja sama perdagangan dengan wilayah-wilayah yang dilalui dalam perjalanan tersebut. Kerja sama perdagangan ini, di samping melakukan pertukaran komoditi juga meminta jaminan keamanan kepada pemimpin wilayah sepanjang rute-rute perdagangan yang dilalui. Kerja sama jaminan keamanan perdagangan ini sering di sebut dengan istilah ilaf.

Dengan adanya ilaf ini, kafilah-kafilah dagang Arab diizinkan secara bebas pergi melalui wilayah tersebut, seperti seperti Syria. Disamping Hashim, beberapa Quraisy lainnya mendapat ilaf dari negara-negara tetangga. Diantaranya, Abd Sham ibn Abd Manaf mendapat piagam dari pemerintahan atau kekaisaran Iraq dan Persia, dan begitu pula ketika Abd Muthalib bin Abd Manaf menerima piagam yang sama dari pemerintah al-Himyar dan al-Yaman. Keempat orang tersebut merupakan keturunan dari Abdul Manaf. 
Disamping itu, ada juga sejarawan yang mengatakan bahwa pedagangpedagang Mekkah menjadi bersifat internasional sejak dulu dan berhenti pada waktu yang tidak diidentifikasi pada masa sebelum Islam.

Sekalipun apa perbedaan dalam menentukan orang yang paling awal melakukan hubungan dagang internasional, namun mereka sepakat bahwa orangorang Mekah sudah dikenal sebagai pedagang yang mendunia sebelum lahirnya Islam. Argumen untuk mendukung pernyataan tersebut, disamping letak geografis sebagaimana dijelaskan di atas, juga adan ya konsep al-Haram.

\section{b. Produk dan Bentuk Kegiatan Usaha}

Organisasi perdagangan kafilah merupakan persatuan seluruh penduduk untuk melakukan pertemuan, perdagangan, memberikan arahan dan komunikasi kepada masyarakat luas melalui kurir orang badui. Organisasi kafilah tersebut, terdiri dari orang-orang yang membawa barang-barang dagangan yang disebut latimah, dan yang perlengkapan makanan yang disebut rikab (Mahmood Ibrahim, Merchant Capital and Islam, Austin: University of Texas, $1990 \mathrm{hlm}$ 79).

Kafilah ini berangkat dan kembali pada peristiwa-peristiwa penting untuk kepentingan umum dan yang menjadi perhatian mereka. Para kafilah Mekkah, melalui rute Hijaz masuk ke Romawi melalui wilayah Ayla di pusat teluk Aqobah dan ia merupakan tempat pemberhentian ketika melakukan perjalanan dari Laut Merah ke Palestina dan Adhri'at. Kafilah yang berjalan menuju Gazza, pelabuhan laut di selatan Palestina, membawa barang dagangan ke kota-kota Mediterania (laut tengah) lainnya dan beberapa di antaranya berhenti di Busra Syria. Di kota ini, kafilah-kafilah Mekah menyerahkan barang-barang mereka ke pembeli yang sudah ditetapkan/ ditunjukan oleh negara tersebut. Kita-kota ini merupakan gerai modal (principal outlet) dan pasar bebas untuk komoditi orang-orang Mekkah.

Para kafilah ini pada saat kembali ke Mekkah, mereka membawa minuman keras, kulit, buah-buahan, madu, dan sayur-mayur dari Thaif, sedangkan batanganbatangan emas, perak, emas abu-abu dari Afrika. Parfum-parfum, rempah-rempah, pakaian dan obat-obatan di bawa kembali dari Arabia selatan, india, dan Afrika. Di bawah itu, sutra dibawa dari Cina, pakaian dari Aden, budak, buruh, serdaduserdadu, dan gading dari Afrika Timur melalui Yaman. Produk-produk industri yang lux, seperti kapas, linen atau bahan sutra di bawa dari negara-negara Laut 
Tengah, Mesir dan Syria. Semua barang-barang yang dibeli dengan harga tinggi, dianggap sebagai barang lux di negara-negara yang berada di Barat atau di Timur. Beberapa barang ini ditemukan oleh mereka dalam perjalanan ke wilayah kekaisaran Romawi (M.Daud Bakar, Contract in Islamic Commercial and Their Application in Modern Islamic Financial System,Kuala Lumpur 2004 hlm. 26).

c. Mata Uang dan Alat Pembayaran

Sebagaimana dimaklumi bahwa prasyarat untuk melakukan transaksi adalah adanya mata uang dan alat pembayaran yang dapat dipercaya. Arabia dan wilayahwilayah sekitarnya sebelum Islam, berada langsung di bawah kekuasaan Persia dan Romawi. satuan uang yang dipergunakan negara-negara tersebut adalah dirham dan dinar. Dinar dibuat dari emas sedangkan dirham berasal, dari persia. Romawi, persia, dan Mesir di antara negara-negara yang menggunakan standar emas (ahl aldzahab) dan Babilonia merupakan negara yang menggunakan standar perak (ahl alwaraq). Dengan digunakannya satuan uang dinar dan dirham tersebut, maka bangsa Persia dan bangsa Romawi menjadi mitra dagang orang-orang Arab.

Oleh karena itu, di Mekkah satuan uangnya adalah dinar dan dirham. Para pedagang di Mekkah melakukan transaksi dan investasi dengan satuan uang tersebut. Bahkan mereka menilai uang tersebut sebagai komoditi yang dapat diperdagangkan. Mereka menganggap perdagangan uang ini merupakan bentuk dari jual beli.

\section{d. Mekkah Menjadi tempat "Perbankan"}

Pada akhir abad ke- 7 dengan eskalasi jaringan perdagangan yang cukup luas. Menurut para ahli, peraktik-peraktik perbankan, proto-banking, dan pertukaran uang telah berkembang dan mengalami kemajuan olah kelompok yang berkuasa di Persia, Basrah, dan ahli Keuangan Yahudi yang sering melakukan perdagangan diantara mereka. Sebagaimana diungkapkan oleh Rayner, bahwa Hijaz sebelum Islam adalah tempat istirahat rute-rute perjalanan kafilah yang kemudian berkembang menjadi clearing house dari para pemilik uang (S.E. Rayner, the theory of Contract in Islamic Law, London : Graham and Trotman, hlm 75)

Oleh karena itu, tampak jelas bahwa instrumen kredit sejenis cek uang sudah bisa digunakan diantara kelompok-kelompok perdagangan yang disebut dengan hawala (seperti Letter of Credit dan Bill of Exchange). Instrumen lain yang 
berbentuk kewajiban-kewajiban tertulis dikenal dengan istilah suftaja semacam bentuk commercial paper. Dalam perdagangan perseorangan, suftaja berlaku untuk sejumlah 42.000 dinar. Suftaja ini dipergunakan untuk melakukan pembayaran transaksi perdagangan trans-sahara dan terutama di Irak. Di samping itu, suftaja juga berfungsi sebagai alat pembayaran pajak dan petani-petani di provinsi untuk di setor ke pemerintah pusat. Dengan adanya sejenis cek tersebut, pengusaha dapat melakukan pembayaran ke berbagai wilayah dan negara yang jauh sekalipun.

\section{Perdagangan di jazirah Arab pada awal pemerintahan Islam}

a. Perdagangan bersekala kecil dan sekala besar

Sebagaimana yang sudah dijelaskan, bahwa kondisi daerah hijaz sangat menguntungkan karena terletak antara tiga benua serta memberikan keuntungan tersendiri karena dilalui rute perdagangan antara Persia dan Romawi dan negara jajahan yaitu Syam, Ethiopia, dan Yaman. Ekspansi yang di lakukan Islam ke wilayah kekaisaran Romawi (Syam, Mesir, Andalusia) dan kekaisaran Persia, (Iran, Irak, Bahrain dan Transoxania) menyebabkan perputaran mata uang semakin meningkat bahkan pada jaman pemerintahan Imam Ali, dinar dan dirham menjadi satuan mata uang yang digunakan.

Pada masa pemerintahan Umar, administrasi keuangan di Baitul Mal didelegasikan kepada orang - orang Persia yang bertugas mengatur pengeluaran dan pemasukan dan menggunakan satuan dirham untuk membantu meningkatkan sirkulasi uang.

Selain dinar dan dirham, alat pembayaran pada periode awal Islam adalah kredit, kredit memiliki keuntungan tersediri misalnya, untuk melakukan transaksi yang nilainya cukup tinggi tentu dibutuhkan koin-koin yang banyak sebagai alat pembayaran tentu hal ini di pandang tidak praktis, berat dan volume koin-koin tersebut mengurangi daya tarik (Hasanuz zaman, the Economic Functions of The Early Islamic State (Karachi: International Islamic Publihers,2001) hlm 337).

Biasanya para pedagang yang berpengalaman menggunakan surat wesel dengan dan syarat uang dalam transaksi bisnisnya. Pada perkembangan selanjutnya, dalam transaksi yang dilakukan secara kredit kedua pelaku saling menyerahkan bukti penerimaan sebagai peraturan kredit. Jika surat-surat utang ini juga digunakan 
oleh pedagang - pedagang lain, bukti penerimaan ini dapat diterima sebagai alat pembayaran dan sama nilainya dengan uang.

\section{Penawaran dan Permintaan Uang.}

Pada masa awal pemerintahan Nabi Muhammad SAW di Madinah, dua jenis mata uang yang di pakai yaitu dinar dan dirham, dua jenis mata uang ini masih di impor, yaitu dinar dari Roma dan dirham dari Persia. Besarnya volume impor dinar dan dirham dan juga barang-barang komoditas bergantung kepada volume komoditas yang diekspor ke kedua negara tersebut dan ke wilayah- wilayah yang berada di bawah kekuasaannya. Biasanya, jika permintaan uang (money demand) pada pasar internal meningkat maka uanglah yang di impor. Sebaliknya, bila permintaan uang turun maka komoditaslah yang di impor. Hal yang cukup menarik di sini adalah tidak adanya pembatasan terhadap impor uang karena permintaan internal dari Hijaz terhadap dinar dan dirham sangat kecil sehingga tidak berpengaruh terhadap penawaran (supply) dan permintaan (demand) dalam perekonomian Roma dan Persia. Walaupun demikian, selama pemerintahan Rasulullah uang tidak di penuhi dari keuangan negara semata melainkan dari hasil perdagangan dengan luar negeri (Adiwarman Azwar Karim, Ekonomi Islam: Suatu Kajian Kontemporer, Jakarta : Gema Insani Press, 2002. hlm 64).

Setelah Persia di taklukan, percetakan uang logam di wilayah tersebut tetap beroperasi. Sementara itu, kaum muslimin secara perlahan mulai di per kenalkan kepada teknologi percetakan uang sehingga pada masa kepemimpinan Imam Ali kaum Muslimin secara resmi dapat mencetak uang sendiri dengan menggunakan nama pemerintahan Islam. Ketika mata uang masih di impor, kaum muslimin hanya mengontrol kualitas uang impor itu, namun setelah dapat mencetak sendiri kaum muslimin secara langsung mengawasi peredaran uang yang ada. Kepemimpinan imam Ali yang sangat singkat di tambah dengan eskalasi ketegangan politik yang terjadi pada saat itu menyebabkan uang yang di cetak tidak dapat beredar luas.

Tinggi rendahnya permintaan uang bergantung pada frekuensi perdagangan dan jasa. Sementara itu, situasi yang kurang kondusif, permusuhan kaum Quraisy terhadap kaum muslimin, dan keterlibatan kaum muslimin dalam 26 Ghazwah (perang yang di ikuti nabi secara langsung) dan 32 Sariyah (perang yang terjadi pada masa kepemimpinan nabi, tetapi beliau tidak terlibat secara langsung), 
menimbulkan precautinary demand (permintaan uang untuk pencegahan) untuk berjaga-jaga terhadap kebutuhan yang tidak di duga dan bersifat tiba-tiba. Jadi dapat di simpulkan bahwa penggunaan uang pada periode ini pada umumnya bersifat permintaan transaksi dan pencegahan.

\section{KESIMPULAN}

Kultur masyarakat Arab yang gemar berdagang telah membawa pengaruh yang cukup signifikan bagi perkembangan ekonomi Islam, tidak hanya bagi lingkup masyarakat Hijaz (jazirah Saudi) tapi juga bagi negara-negara di sekitarnya. Adanya organisasi kafilah dagang yang teroganisir juga menjadi bukti bahwa perdagangan di jazirah Arab sudah cukup maju dan berkembang. Eskalasi jaringan perdagangan yang cukup luas tersebut telah menimbulkan praktik "perbankan", proto banking, dan peningkatan transaksi keuangan yang cukup besar. Demikian juga dengan penggunaan media transaksi bagi perdagangan dan jasa, penggunaan dua jenis mata uang "favorit" yaitu dinar dan dirham yang telah di pakai baik sebelum pemerintahan Islam maupun awal pemerintahan Islam, telah memberikan gambaran secara jelas dan nyata bahwa ekonomi Islam ikut memberikan andil yang cukup besar bagi perkembangan Islam secara keseluruhan.

\section{REFERENSI}

Abdullah Alwi Haji Hassan, 1994, Sales and Contracs in Early Islamic Commercial Law, IRI (Internasional Islamic University)

Adiwarman A. Karim, 2002, Ekonomi Islam Suatu Kajian Kontemporer, Gema Insani Press, Jakarta

Hasanuz Zaman, 2001,The Economic Functions of the Early Islamic State, International Islamic Publishers.

Mahmood Ibrahim, 1990 Merchant Capital and Islam, Austin : University of Texas.

M. Daud Bakar, 2004, Contract in Islamic Commercial and Their Application in Modern Islamic Financial System, Kuala Lumpur.

M. Umer Chapra, 2001, The Future of Economics an Islamic Perspective, Shariah Economics and Banking Institute, Jakarta.

S.E. Rayner, 2001, The Theory of Contract In Islamic Law, Graham and Trootman , London. 